\title{
Antioxidant properties of a tilapia (Oreochromis niloticus) diet with the inclusion of avocado by-product
}

\author{
Propiedades antioxidantes de una dieta para tilapia (Oreochromis niloticus) con inclusión de \\ subproducto de aguacate
}

\begin{abstract}
Edgar Iván Jiménez-Ruíz', Javier Germán Rodríguez-Carpena², Gabriela Poleth Hernández-Ortega ${ }^{3}$, María Teresa Sumaya-Martínez', Rosendo Balois-Morales', Leticia Mónica Sánchez-Herrera', Viridiana Peraza-Gómez ${ }^{4 *}$

Unidad de Tecnología de Alimentos, Secretaría de Investigación y Posgrado, Universidad Autónoma de Nayarit, Ciudad de la Cultura s/n, C.P. 63000, Tepic, Nayarit, México.

2 Unidad Académica de Medicina Veterinaria y Zootecnia, Universidad Autónoma de Nayarit, Carretera CompostelaChapalilla km 3.5, C.P. 63700, Compostela, Nayarit, México.

Programa de Maestría en Ciencias Biológico Agropecuarias, Universidad Autónoma de Nayarit, Carretera Tepic-Compostela km 9, C.P. 63780, Xalisco, Nayarit, México.

${ }^{4}$ Unidad Académica Escuela Nacional de Ingeniería Pesquera, Universidad Autónoma de Nayarit, Carretera a San Blas km. 12, C.P. 63740, Bahía de Matanchén, San Blas, Nayarit, México.
\end{abstract}

\section{ABSTRACT}

Since synthetic antioxidants have been questioned for their potential carcinogenic and teratogenic effects, interest has grown in aquaculture for alternatives of natural antioxidants used in diets. This study analyzed antioxidant properties of a diet for tilapia with the inclusion an avocado by-product (AP) paste. Avocado seed, skin and pulp, despite their proven antioxidant capacity, represent a great amount of waste in Mexico. We included four diets in this study: base diet 0 (BD), 10 (D10), 20 (D20) and $30 \%$ (D30) of AP inclusion, and a commercial diet (CD) for comparison. 2,2'-azino-bis (3-ethylbenzothiazoline-6-sulfonic acid (ABTS•+), iron ion reduction (Fe III) and concentration of total phenolic compounds (TPC). An increasing pattern was observed both in antioxidant activity and TPC as the level of AP inclusion increased. In some determinations, CD showed the highest levels, which were attributed to the synthetic antioxidants added and undeclared in these formulations. Therefore, AP was considered a good option for its inclusion in aquaculture diets because of its antioxidant properties and the added value granted with its use.

Keywords: avocado paste, by-product, antioxidant properties, diet, tilapia.

\section{RESUMEN}

En la acuicultura existe interés por utilizar antioxidantes de origen vegetal como alternativa en la elaboración de dietas, ya que los sintéticos son cuestionados por su potencial efecto cancerígeno y teratogénico. En este estudio se analizaron las propiedades antioxidantes de una dieta para tilapia con inclusión de pasta de subproducto de aguacate (PA). Este representa una gran cantidad de desperdicios en México, sin embargo, se ha comprobado su capacidad antioxidante. Se formularon cuatro dietas con inclusiones de 0 (DB), 10 (D10), 20 (D20) y $30 \%$ (D30) de inclusión de PA y una dieta comercial (DC) como comparación. La actividad antio-

\footnotetext{
*Autor para correspondencia: Viridiana Peraza-Gómez

Correo electrónico: viridianaperaza@hotmail.com

Recibido: 8 de marzo de 2019

Aceptado: 21 de mayo de 2019
}

xidante se evaluó mediante técnicas con radicales como el 1,1-difenil-2-pricrilhidracil (DPPH•), acido-2,2'-azinobis-3-etilbenzotiazolin-6-sulfónico (ABTS•+), reducción del ion férrico (Fe III) y concentración de compuestos fenólicos totales (CFT). Se observó un patrón de aumento tanto en la actividad antioxidante como en los CFT a medida que se incrementó el nivel de inclusión de PA. En algunas determinaciones, DC mostró los valores más altos y se atribuye a antioxidantes sintéticos que se agregan sin ser declarados en estas formulaciones. Por lo anterior, PA se considera una buena opción para incluirla en dietas acuícolas debido a sus propiedades antioxidantes y al valor agregado que se le puede otorgar con su utilización.

Palabras clave: pasta aguacate, subproducto, propiedades antioxidantes, dieta, tilapia

\section{INTRODUCTION}

Tilapia Oreochromis niloticus is a species that belongs to the Cichlidae family, native to Africa and valued in aquaculture industry because it shows tolerance to diseases and other biotic and abiotic factors, placing it as a species in high demand (Meyer et al. 2006). It is an omnivorous organism, and for this reason, its diet includes proteins, vegetable oils, aquatic plants, animal by-products, fermented yeast; in some cases, it includes agricultural-industrial by-products in commercial feed (González-Salas et al., 2014).

Currently, balanced feed is the input of the greatest economic impact in aquaculture since it represents from 40 to $60 \%$ of the production costs (De Silva and Hasan, 2007). It mainly contains synthetic antioxidants, such as butylhydroxyanisole (BHA) and buthylhydroxytoluene (BHT), used as additives in food and susceptible products to lipid oxidation. Nonetheless, their cytotoxic and carcinogenic effects have been proven (Laguerre et al., 2007), which is why the food industry has shown a growing interest in substituting synthetic 
antioxidants for natural ones, both in diets for human and animal consumption (Thorat et al., 2013).

Furthermore, tilapia aquaculture, as for other species, can show pathological events due to management stress or adverse environmental conditions, such as high ammonium concentration $(>1 \mathrm{ppm})$, low temperature $\left(<20^{\circ} \mathrm{C}\right)$ and dissolved oxygen levels $(<2 \mathrm{mg} / \mathrm{L})$, etc. This situation, in turn, may also trigger mortalities that affect productivity and profitability. Consequently, diet with antioxidant properties and natural bioactive compounds could be a key factor in organism health when facing events, such as oxidative stress (Tacon, 1989). Nowadays, vegetal sources with high content of proteins, lipids, and bioactive compounds (mainly antioxidants) can be utilized to generate functional diets that promote health, create stress resistance, decrease diseases within culture systems and minimize production costs (Escobar-Briones et al., 2006).

Avocado (Persea americana Mill.) is a subtropical fruit, native to southern Mexico, which can now be found in America, Australia, South Africa and Spain (FAO, 2005). In 2017, Mexico generated 2.29 million $t$ of avocado, placing it as the main producer worldwide. Avocado Hass is the most popular variety in the international market for its by-products and industrial goals (SIAP, 2018). More than $10 \%$ of avocado production could be used to feed different types of animal species or as material for diet formulation (Avilés-Ríos et al., 2009). Avocado has aroused a great interest because of its high-quality nutritional content and bioactive compounds, such as essential fatty acids, high antioxidant power in its tissues, high carotenoid concentration and phenolic compounds, among others. Therefore, notable technological applications have been considered for avocado, as well as a natural additive and healthy food promotor (RodríguezCarpena et al., 2011). Based on the previous information, this study analyzed the inclusion of avocado by-product in functional food with antioxidant properties designed for tilapia that could promote its health and adequate growth.

\section{MATERIALS AND METHODS Experimental diets}

The avocado by-product was produced from fruit, which came from regional packing companies in Xalisco, Nayarit, Mexico, unsuitable for commercialization, for either inadequate size, alteration, spots, abrasion or lesion in the epithelium. Subsequently, the seed was removed manually to grind the pulp and skin in a hammer blade forage grinder until a homogeneous paste was obtained; then, it was vacuum packed and stored at $7{ }^{\circ} \mathrm{C}$ until use. Four experimental diets were formulated for tilapia adults, according to the base formulation proposed by Bureau and Cho (1994), all with 35 $\%$ protein and $10 \%$ lipids (Table 1 ), producing pellets in a meat grinder (Torrey Model 22) and drying for $12 \mathrm{~h}$ at $45^{\circ} \mathrm{C}$. The inclusion of avocado by-product was adjusted to levels of 10,20 and $30 \%$ in wet basis (D10, D20 and D30). The base diet (BD) was made without the inclusion of avocado paste, while the commercial diet (CD: $35 \%$ protein and $10 \%$ lipids)
Table 1. Formulation of the base diet (BD) and diets with avocado byproduct inclusion at 10, 20 and $30 \%$ (D10, D20 and D30).

Tabla 1. Formulación de dieta base (BD) y dietas con inclusión de subproducto de aguacate al 10, 20 y $30 \%$ (D10, D20 y D30).

\begin{tabular}{|c|c|c|c|c|}
\hline \multirow[t]{2}{*}{ Component (g/100g) } & \multicolumn{4}{|c|}{ Experimental diets } \\
\hline & BD & D10 & D20 & D30 \\
\hline Wheat meal & 40.40 & 34.20 & 31.70 & 26.05 \\
\hline Soy meal & 19.10 & 19.40 & 14.30 & 12.80 \\
\hline Fish meal $^{d}$ & 21.70 & 21.40 & 21.10 & 20.80 \\
\hline Gluten & 5.00 & 5.00 & 5.00 & 5.00 \\
\hline Fish oilc & 11.30 & 7.50 & 5.40 & 2.85 \\
\hline Unflavored gelatin & 1.50 & 1.50 & 1.50 & 1.50 \\
\hline Avocado paste & 0.00 & 10.00 & 20.00 & 30.00 \\
\hline Vitamin Premix & 0.50 & 0.50 & 0.50 & 0.50 \\
\hline Mineral Premix ${ }^{b}$ & 0.50 & 0.50 & 0.50 & 0.50 \\
\hline
\end{tabular}

a Vitamin Pre-mix: Vitamin A, $536 \mathrm{KUI} / \mathrm{kg}$; Vitamin $\mathrm{D}_{3^{\prime}}, 133.5 \mathrm{KUI}$; Vitamin E, 6,666.5 mg; Vitamin $\mathrm{K}_{3}, 666.862 \mathrm{mg}$; Vitamin B1 1,000.04 mg; Vitamin $\mathrm{B}_{2}$, 1,000 mg; Vitamin $B_{6}, 1,333.32$ mg; Vitamin $B_{12^{\prime}} 1.33$ mg; vitamin C, 10,000.2 mg; Niacin, 5,334.195 mg; Pantothenic acid, 2,666.7 mg; Folic acid, 332.8 mg; Biotin, 33.3 mg; Choline chloride, 40,020.6 mg. DSM Nutritional Products México S. A. de C. V.

${ }^{b}$ Mineral Pre-mix: Copper, 46 mg/kg, Iron, 133.44 mg; Manganese 282.56 mg; Cobalt, 4.15 mg; lodine, 20.6 mg; Zinc, 871.56 mg; Selenium, 0.5 mg; Magnesium, $282.56 \mathrm{mg}$. DSM Nutritional Products México S. A. de C. V. ${ }^{c d}$ Maz Industrial S.A de C.V: Mazatlán, Sinaloa.

a Pre-mezcla de vitaminas: Vitamina A, $536 \mathrm{KUI} / \mathrm{kg}$; Vitamina D3, $133.5 \mathrm{KUl}$; Vitamina E, 6,666.5 mg; Vitamina K3, 666.862 mg; Vitamina B1 1,000.04 mg; Vitamina B2, 1,000 mg; Vitaminas B6, 1,333.32 mg; Vitamina B12, 1.33 mg; Vitamina C, 10,000.2 mg; Niacina, 5,334.195 mg; Ácido pantoténico, 2,666.7 mg; Ácido fólico, 332.8 mg; Biotina, 33.3 mg; Cloruro de colina, 40,020.6 mg. DSM Nutritional Products México S. A. de C. V.

${ }^{\text {b }}$ Pre-mezcla de minerales: Cobre, $46 \mathrm{mg} / \mathrm{kg}$, Hierro, $133.44 \mathrm{mg}$; Manganeso $282.56 \mathrm{mg}$; Cobalto, $4.15 \mathrm{mg}$; Yodo, $20.6 \mathrm{mg}$; Zinc, $871.56 \mathrm{mg}$; Selenio, 0.5 mg; Magnesio, 282.56 mg. DSM Nutritional Products México S. A. de C. V.

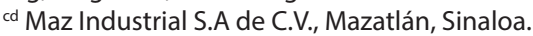

was acquired from a local establishment (PRONUA, SA de CV, México).

\section{Proximal analysis}

Before formulating the experimental diets, we performed a proximal analysis of the raw materials, which consisted on determining humidity, lipids, protein, and ashes, also performed to the experimental diets, with the addition of fiber determination (A.O.A.C., 2012).

\section{Ethanolic extraction}

To assess antioxidant properties, three samples were taken at random of the formulated diets in the laboratory, commercial diet, and avocado paste (previously lyophilized) with a weight of $7.5 \mathrm{~g}$; subsequently, samples were dissolved in $150 \mathrm{~mL}$ of ethanol. The extraction was performed with a Soxhlet equipment for three hours of reflux; the extracts were filtered with Whatman \#4 filters and stored at $4{ }^{\circ} \mathrm{C}$ until subsequent analyses based on the method described by Maisuthisakul et al. (2009). In the case of avocado paste, at 
the end of the analyses, results were converted to wet basis as it was used during diet formulation.

\section{Antioxidant activity}

\section{$D P P H \cdot$ scavenging activity}

The determination was performed according to the methodology reported by Morales and Jiménez-Pérez (2001), using the stable free radical DPPH• as an assay method. Results are expressed in $\mu \mathrm{mol}$ equivalent to Trolox $/ \mathrm{g}$ ( $\mu \mathrm{mol}$ ET/g), making a standard Trolox (6-Hydroxy-2, 5, 7, 8-tetramethylchroman-2-carboxylic acid) curve from 0 to 500 $\mathrm{mol} / \mathrm{L}$.

\section{ABTS•+ scavenging capacity}

The scavenging ability of the stable cation ABTS•+ was determined according to the method reported by $\mathrm{Re}$ et al. (1999) and Kuskoski et al. (2004). The assay radical was determined with the ABTS -+ reactive at a concentration of $7 \mathrm{mM}$ with potassium persulfate at $2.45 \mathrm{mM}$, incubated at an approximate temperature of $7{ }^{\circ} \mathrm{C}$ and in darkness for 16 h. Once the ABTS-+ radical was formed, it was diluted with ethanol until an absorbance of $0.700( \pm 0.1)$ at $754 \mathrm{~nm}$ was obtained. The reference antioxidant was Trolox, assayed at a 0-1.5 $\mathrm{mM}$ concentration range, expressing the results in $\mathrm{mmol}$ Trolox equivalent/g of sample (mmol TE/g).

Ferric Reducing Antioxidant Power (FRAP)

Reduction ability of Fe (III) ion to Fe (II) ion was performed following the method of Hinneburg et al. (2006). Determination was performed at an absorbance of $700 \mathrm{~nm}$, and ferric reduction (III) was determined as Trolox equivalent ( $\mu \mathrm{mol} \mathrm{TE} / \mathrm{g})$.

\section{Determination of total phenolic compounds (TPC)}

The phenolic compounds were analyzed using the Folin-Ciocalteu reaction and according to that reported by Stintzing et al. (2005). Compound concentration was obtained from a standard curve of gallic acid ( 0 to $400 \mathrm{mg} / \mathrm{L}$ ), from which the results were calculated as $\mathrm{mg}$ gallic acid equivalent/gram of sample (mg GAE)/g).

\section{Statistical analysis}

For data analysis, we used a completely randomized design, subjecting results to a one-way analysis of variance (ANOVA), taking as a main factor the five diet types (including the commercial diet). A Tukey's mean comparison test was performed, considering a significance level of $5 \%(p<0.05)$. All analyses were performed with the software IBM SPSS Statistics 2.0.

\section{RESULTS AND DISCUSSION}

\section{Experimental diets}

Table 2 shows the proximal composition of the ingredients used for the experimental diet formulations, highlighting that the protein ingredients were unflavored gelatin, gluten and fish meal with $84.04 \pm 0.48,65 \pm 0.17$ and $55.92 \pm 0.11 \%$ of protein, respectively. Likewise, the ingredients with greater lipid content were fish oil ( $97.57 \pm 0.37 \%)$, followed by avocado paste (AP) with a percentage of $13.81 \pm$
Table 2. Proximal composition of the components used in experimental diet formulation in wet basis (\%).

Tabla 2. Composición proximal de los insumos utilizados en la formulación experimental de la dieta en base húmeda (\%).

\begin{tabular}{lcccc}
\hline Component & Humidity & Proteins & Lipids & Ashes \\
\hline Wheat meal & $12.71 \pm 0.19$ & $13.02 \pm 0.28$ & $1.80 \pm 0.03$ & $0.60 \pm 0.02$ \\
Soy meal & $10.55 \pm 0.04$ & $43.05 \pm 0.28$ & $0.55 \pm 0.07$ & $6.19 \pm 0.17$ \\
Fish meal & $12.03 \pm 0.25$ & $55.92 \pm 0.11$ & $2.10 \pm 0.08$ & $18.94 \pm 0.07$ \\
$\begin{array}{l}\text { Unflavored } \\
\text { gelatin }\end{array}$ & $11.04 \pm 0.29$ & $84.04 \pm 0.48$ & $0.08 \pm 0.01$ & $1.89 \pm 0.04$ \\
$\begin{array}{l}\text { Gluten } \\
\text { Fish oil }\end{array}$ & $0.53 \pm 0.18$ & $65.00 \pm 0.17$ & $1.44 \pm 0.20$ & $0.80 \pm 0.05$ \\
$\begin{array}{l}\text { Avocado } \\
\text { paste }\end{array}$ & $70.93 \pm 0.22$ & $1.37 \pm 0.01$ & $13.81 \pm 0.20$ & $4.25 \pm 0.32$ \\
\hline
\end{tabular}

Values represent the mean and standard deviation $(n=3)$.

ND: Not determined.

0.20, which was closer to that reported by Hernández-López (2016) for AP in which pulp, skin and seed were included (14.16\%).

In the proximal analyses of the experimental diets (Table 3), no significant differences ( $p>0.05)$ were observed for the percentage of the main components (protein and lipids). In the proximal analysis of the experimental diets (Table 3), there were significant differences $(p<0.05)$ for the percentage of the main components. However, these components keep with the established requirements for the study organisms (protein $\approx 35 \%$ and lipids $\approx 10 \%$ ). In the case of fiber, it is considered indigestible because tilapia does not have the enzymes required for its digestion. Nonetheless, it is well-known that its contribution in diets is essential to modulate food transit through the gastrointestinal tract and facilitate nutrient absorption. Furthermore, cellulase activity is present in microorganisms that colonizes $O$. mossambica intestine (Saha et al., 2006). According to that indicated by the Secretaría de Agricultura, Ganadería, Desarrollo Rural, Pesca y Alimentación (SAGARPA, 2009) in Mexico, in general, crude fiber levels in food for tilapia should not be greater than $5 \%$. It is important to point out that the formulated diets did not go beyond the maximum composition level of crude fiber with the exception of CD.

On the other hand, CD was the one with highest

Table 3. Proximal composition of experimental diets (\%).

Tabla 3. Composición proximal de las dietas experimentales (\%)

\begin{tabular}{lccccc}
\hline Diets & Moisture & Protein & Lipids & Ashes & Fiber \\
\hline CD & $7.94 \pm 0.07^{\mathrm{a}}$ & $35.34 \pm 0.41^{\mathrm{b}}$ & $9.40 \pm 0.24^{\mathrm{b}}$ & $9.75 \pm 0.06^{\mathrm{a}}$ & $5.70 \pm 0.45^{\mathrm{a}}$ \\
BD & $6.14 \pm 0.10^{\mathrm{c}}$ & $36.11 \pm 0.25^{\mathrm{a}}$ & $9.83 \pm 0.07^{\mathrm{a}}$ & $7.77 \pm 0.28^{\mathrm{cd}}$ & $1.23 \pm 0.13^{\mathrm{d}}$ \\
\hline D10 & $6.61 \pm 0.19^{\mathrm{b}}$ & $36.40 \pm 0.21^{\mathrm{a}}$ & $9.60 \pm 0.12^{\mathrm{b}}$ & $7.62 \pm 0.11^{\mathrm{d}}$ & $1.68 \pm 0.38^{\mathrm{cd}}$ \\
\hline D20 & $5.66 \pm 0.21^{\mathrm{d}}$ & $35.78 \pm 0.45^{\mathrm{ab}}$ & $9.54 \pm 0.24^{\mathrm{b}}$ & $7.92 \pm 0.01^{\mathrm{c}}$ & $2.03 \pm 0.04^{\mathrm{c}}$ \\
\hline D30 & $5.48 \pm 0.17^{\mathrm{d}}$ & $36.42 \pm 0.29^{\mathrm{a}}$ & $9.87 \pm 0.08^{\mathrm{a}}$ & $8.53 \pm 0.14^{\mathrm{b}}$ & $2.50 \pm 0.20^{\mathrm{b}}$ \\
\hline
\end{tabular}

*CD: Commercial diet; BD: Base diet (0\%); D10, D20 and D30: Diets formulated with 10, 20 and $30 \%$ of avocado paste inclusion, respectively.

**Values represent the mean and standard deviation $(n=3)$. Means in the same column with different superscript are statistically different $(p<0.05)$. 
percentage of ashes, which depends on fish meal used and the amount of minerals added in the preparation of diet, and whose percentage is unknown due to formula confidentiality. Fish meal could have from $10-20 \%$ ashes, but when it is higher than $23 \%$, protein quality and digestibility is decreased (Galleguillos and Romero, 1994). Therefore, fish meal did not represent a risk in the diets made in this study since ash percentage was $18 \%$ and its inclusion decreased as the level of AP inclusion increased.

\section{Antioxidant activity $\mathrm{DPPH} \bullet$}

In the DPPH $\bullet$ assay results, AP anti-radical activity was $5.14 \pm 0.04 \mu \mathrm{mol} T E / \mathrm{g}$, which is three times greater than the previously reported for avocado Hass pulp (Wang et al., 2012; Moreno et al., 2014). The previous results could be due to the presence of carotenoids, tocopherols, tocotrienols and other phenolic compounds that were present in greater proportion in skin (Rodríguez-Carpena et al., 2011; Wang et al., 2012; Daiuto et al., 2014). Likewise, the formulated diets showed significant differences $(p<0.05)$ among them (Figure 1$)$ since they increased in the antiradical activity in proportion to AP inclusion. It is worth to point out that no differences ( $p>$ 0.05 ) were found between D30 and CD where the antiradical activity of the latter could be attributed to the addition of synthetic antioxidants (frequently undeclared) or to the concentration of synthetic analogs, for example, vitamin E (Lundebye et al., 2010).

Previously, several experimental diets have been formulated with antioxidant properties and, some of them assessed antiradical ability (against DPPH•). Ahmed et al. (2015) prepared a diet for tilapia with the inclusion of edible mushroom waste; Carbonera et al. (2014) designed an anti-

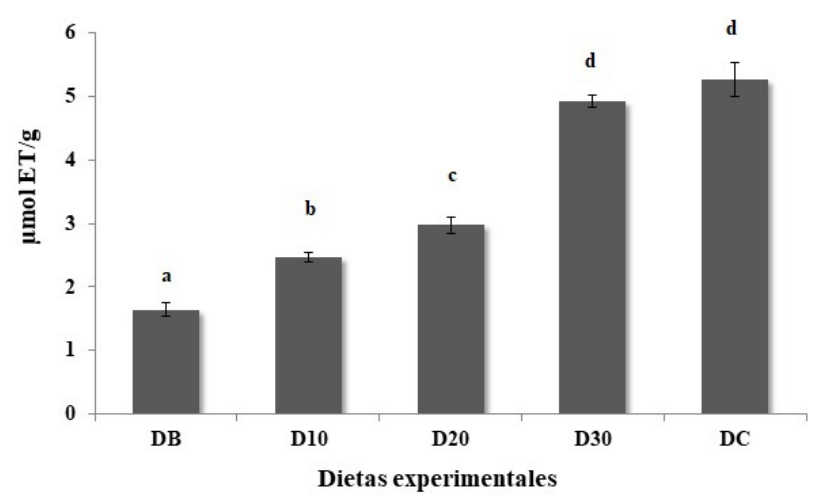

Figure 1. DPPH • free radical scavenger ability of experimental diets. Bars show the average and standard deviation of three replicates. BD: base diet (0 \%); D10, D20 and D30: Diets formulated with 10, 20 and $30 \%$ of avocado paste inclusion; $C D$ : Commercial diet. Different letters in bars indicate significant differences $(p<0.05)$.

Figura 1. Capacidad de atrapamiento del radical libre DPPH• de las dietas experimentales. Las barras muestran el promedio y desviación estándar de tres réplicas. DB: Dieta base (0\%); D10, D20 y D30: Dietas formuladas con 10, 20 y $30 \%$ de inclusión de pasta de aguacate; DC: Dieta comercial. Literales distintas en las barras indican diferencias significativas $(p<0.05)$. oxidant diet for tilapia with residual extract of acerola; Lim and Lee (2011) assessed diets for tilapia including soy meal and fermented cotton seeds with Aspergillus oryzae. Similarly, Kim et al. (2013) supplemented a diet for Paralichthys olivaceus with spirulina and quercetin; and Kim et al. (2009) utilized Korean "Meju" and fermented soy meal also with the same microorganism but in a diet for parrot fish Oplegnathus fasciatus. In general, all these studies attributed the antioxidant ability against DPPH $\bullet$ radical to the content of phenolic compounds in each one of the non-conventional ingredients implemented. As previously mentioned, in the case of this study, the greatest antiradical activity in comparison with the reference diet (BD) could be attributed to different bioactive phenolic compounds present in the by-product used.

\section{$A B T S \cdot+$}

In the ABTS•+ assay, AP showed a scavenger ability of this cation of $78.13 \pm 0.41 \mathrm{mmolTE} / \mathrm{kg}$, which was greater than the reported in avocado Hass pulp by Pellegrini et al. (2003) and Daiuto et al. (2014) with 2.22 and $15.22 \mathrm{mmol}$ TE/kg, respectively. The previous results can be attributed once more to incorporating skin to the paste, since an antiradical activity had been reported related to the lipophilic and hydrophilic compound concentration, mainly carotenoids, tocopherols procyanidins and other phenolic compounds found in this tissue in high concentrations (Rodríguez-Carpena et al., 2011; Wang et al., 2012).

The behavior of the experimental diets (Figure 2) showed that D30 had a maximum increase in scavenger ability against ABTS + with a value of $8.23 \pm 0.22 \mathrm{mmol} E T /$ $\mathrm{kg}$. For this reason, we can consider the inclusion of PA as the increase promotor with respect to the possible bioactive compounds present acting as antioxidants. It is worth

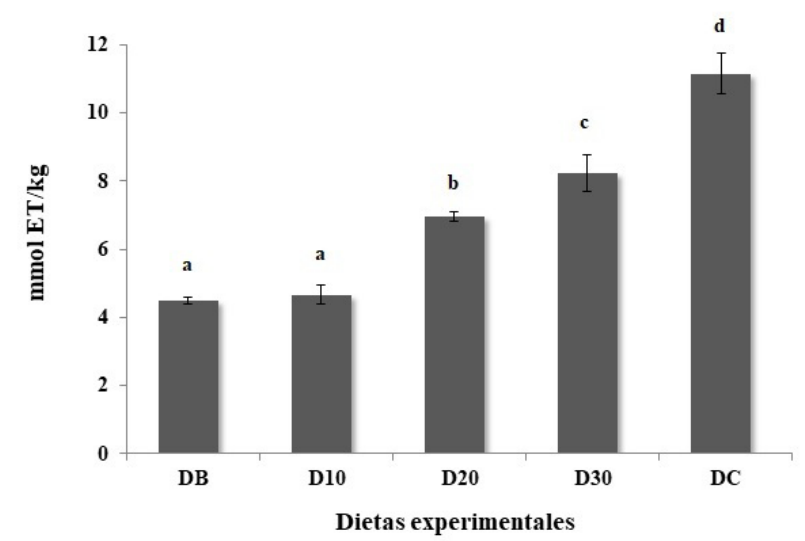

Figure 2. ABTS•+ free radical scavenger ability of experimental diets. Bars show the average and standard deviation of three replicates. BD: base diet (0\%); D10, D20 and D30: Diets formulated with 10, 20 and $30 \%$ of avocado paste inclusion; $\mathrm{CD}$ : Commercial diet. Different letters in bars indicate significant differences $(p<0.05)$.

Figura 2. Capacidad de atrapamiento del radical libre ABTS•+ de las dietas experimentales. Las barras muestran el promedio y desviación estándar de tres réplicas. DB: Dieta base (0 \%); D10, D20 y D30 \%: Dietas formuladas con 10,20 y 30 de inclusión de pasta de aguacate; DC: Dieta comercial. Literales distintas en las barras indican diferencias significativas $(p<0.05)$. 
highlighting that the $\mathrm{CD}$ antioxidant activity in this assay was greater than all diets formulated and produced in the laboratory, which could be attributed to the synthetic antioxidants normally added and frequently undeclared.

At the present time, few studies are available where antioxidant activity in aquaculture diets has been assessed by this radical, since the majority have focused on the analysis of the antiradical DPPH• activity, in some cases together with total phenolic compound determination (Lim and Lee, 2011; Kim et al., 2013; Ahmed et al., 2015). Montoya et al. (2014) implemented diets that included tomato and lycopene extract in functional diets designed for goldfish Carassius auratus and platy Xiphophorus maculatus. The diets with the greatest antiradical ABTS - + ability were those supplemented with $0.6 \%(\mathrm{w} / \mathrm{w})$ with $19.4 \mathrm{mmol} \mathrm{TE} / \mathrm{kg}$, with greater value than that shown by D30 $(8.23 \pm 0.22 \mathrm{mmol} \mathrm{TE} / \mathrm{kg})$. About this, it is important to mention that in the present work we used an avocado by-product, considered waste in current agricultural food industry, instead of a purified commercial product as the lycopene used in the reference study, which is also more expensive.

\section{Ferric Reducing Antioxidant Power}

From the FRAP assay antioxidant activity results, AP showed an ability to reduce Fe (III) ion at $20.23 \pm 0.24$ $\mu \mathrm{mol} \mathrm{TE} / \mathrm{g}$ of sample. Such capacity can be attributed to the presence of phenolic compounds and ascorbic acid in the fruit (Wang et al., 2012). According to previous studies, approximate values of 15-22 $\mu \mathrm{mol}$ ET/g have been reported in avocado Hass pulp (Gorinstein et al., 2011; Moreno et al., 2014), which can be considered close to those found in this study in AP.

The diets formulated in this study were significantly $(p$ $<0.05$ ) affected (Figure 3), showing an increase in their ability to reduce Fe (III) ion according to the inclusion formulation level, in which $\mathrm{D} 30$ recorded the greatest reduction ability in comparison with CD (12.77 $\pm 0.15 \mathrm{mg} \mathrm{TE} / \mathrm{g}$ and $13.26 \pm 0.42$ $\mathrm{mg} \mathrm{TE} / \mathrm{g}$ respectively), without being statistically different ( $p$ $>0.05$ ). In the case of D30 and the rest of avocado by-product formulated diets, the antioxidant activity in this assay can be attributed to the bioactive compounds in this fruit. In the case of $\mathrm{BD}$, to antioxidant compounds present in some base components, such as soy and wheat meal or the pre-mixture of vitamins and minerals (Devi et al., 2009; Lv et al., 2012). With respect to $C D$, its high ability to reduce Fe (III) ion could be attributed in a great measure to the content of synthetic antioxidants added during its formulation.

Similar to the ABTS -+ assay, few studies are available in aquaculture where the antioxidant ability in diets has been assessed through this method. This procedure is important since a clear idea of the type of compounds present can be obtained by performing different tests related to antioxidant properties, as well as the possible mechanisms of action. In general, DPPH assay is considered for hydrophobic compounds, FRAP mainly for hydrophilics, and ABTS •+ for both types function as amphipathic assay (Opitz et al., 2014).

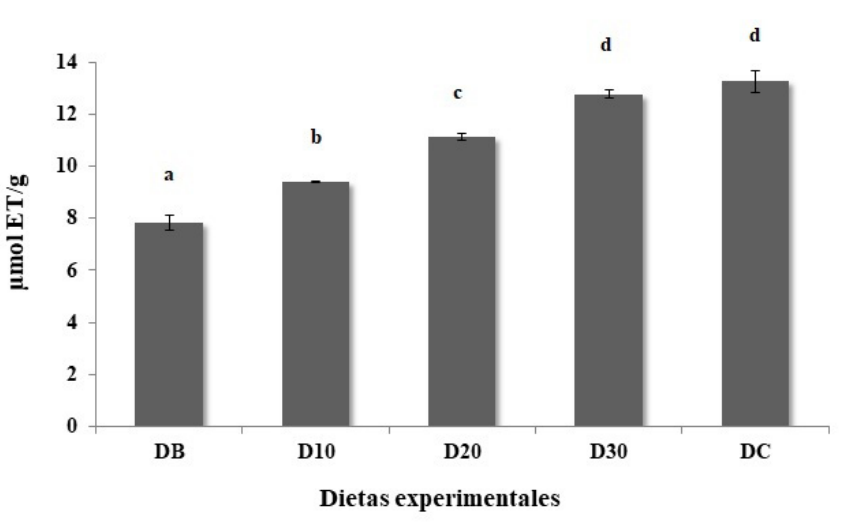

Figure 3. Reduction capacity of Fe (III) ion to Fe (II) ion of the experimental diets. Bars show the average and standard deviation of three replicates. BD: Base diets (0 \%); D10, D20 and D30: Diets formulated with 10, 20 and $30 \%$ of avocado paste inclusion; CD: Commercial diet. Different letters in bars indicate significant statistical differences $(p<0.05)$.

Figura 3. Capacidad de reducción del ion Fe (III) a ion Fe (II) de las dietas experimentales. Las barras muestran el promedio y desviación estándar de tres réplicas. DB: Dieta base (0 \%); D10, D20 y D30: Dietas formuladas con 10, 20 y 30 \% de inclusión de pasta de aguacate; DC: Dieta comercial. Literales distintas en las barras indican diferencias significativas $(p<0.05)$.

\section{Phenolic compounds}

The concentration of phenolic compounds in AP was $20.91 \pm 0.28 \mathrm{mg} \mathrm{GAE} / \mathrm{g}$ of sample. This concentration was 15-20 times greater than the reported by Wang et al. (2010), Moreno et al. (2004) and Daiuto et al. (2004), who found 4.9, 5.82 and $3.3 \mathrm{mg} \mathrm{GAE} / \mathrm{g}$, respectively, in avocado Hass pulp. This could be attributed to skin inclusion of this fruit in AP since a greater concentration of phenolic compounds have been reported in this tissue than in pulp (Daiuto et al., 2004; Wang et al., 2010; Rodríguez-Carpena et al., 2011).

On the other hand, diets showed significant differences with respect to phenolic compound content $(p<0.05)$, observing a clear tendency to increase its values as inclusion of AP increased (Figure 4). Regarding this, D30 was the diet with the greatest concentration of phenolic compounds, including $B D$ and $C D$. As to BD, despite AP was not included during formulation, its phenolic compound concentration was considerable, and it could be attributed to the content in the components used during formulation, such as soy and wheat meal or vitamin pre-mixture (Devi et al., 2009; Lv et al., 2012). Although CD showed a lower concentration than other diets, the presence of these compounds could be attributed to $\mathrm{BHT}, \mathrm{BHA}, \mathrm{BHQT}$ that are synthetic phenolic-type substances normally included in commercial diets (Lundebye et al., 2010).

Few studies are available analyzing aquaculture diets about total phenolic compounds. Obasa et al. (2013) reported $5.6 \mathrm{mg} \mathrm{GAE} / \mathrm{g}$ in a diet for tilapia including seed meal from fermented mango; Oniszczuk et al. (2019) designed a diet for carp utilizing eastern purple coneflower (Echinacea purpurea (L.) Moench.) as part of the components, finding a maximum value of $4.2 \mathrm{mg} \mathrm{GAE} / \mathrm{g}$ in the diet with the greatest inclusion 


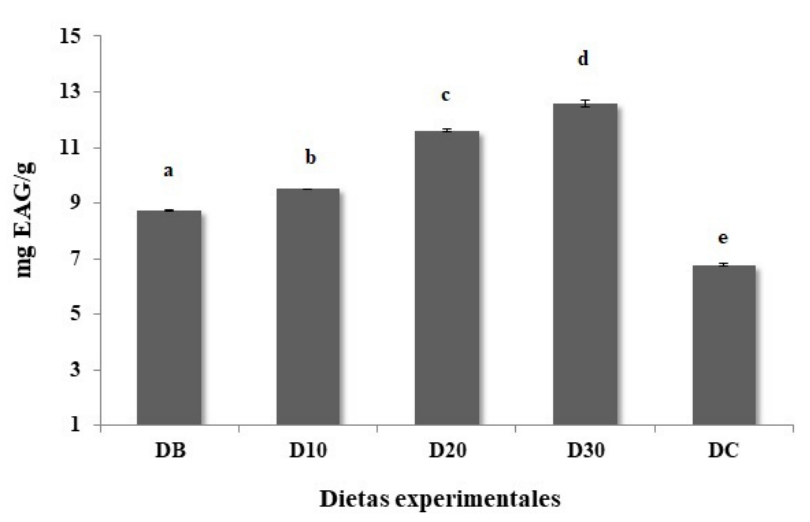

Figure 4. Concentration of total phenolic compounds of the experimental diets. Bars show the average and standard deviation of three replicates. BD: base diet (0\%); D10, D20 and D30: Diets formulated with 10, 20 and $30 \%$ inclusion of avocado paste; CD: Commercial diet. Different letters in bars indicate significant statistical differences $(p<0.05)$.

Figura 4. Concentración de compuestos fenólicos totales de las dietas experimentales. Las barras muestran el promedio y desviación estándar de tres réplicas. DB: Dieta base (0 \%); D10, D20 y D30: Dietas formuladas con 10,20 y $30 \%$ de inclusión de pasta de aguacate; DC: Dieta comercial. Literales distintas en las barras indican diferencias significativas $(p<0.05)$.

of the plant $(60 \mathrm{~g} / \mathrm{kg})$. Lim and Lee (2011) experimented with a diet designed for tilapia including soy meal and fermented cotton seeds, finding values around $3.8 \mathrm{mg} \mathrm{GAE} / \mathrm{g}$. All these values were lower than that found for D30 (best functional diet with $12.58 \pm 0.11 \mathrm{mg} \mathrm{GAE} / \mathrm{g}$ ) in this study, which could be attributed mainly to incorporating avocado by-product as component, that showed a great concentration of these bioactive compounds.

\section{CONCLUSIONS}

As previously mentioned, aquaculture diet components need to have a concentration of bioactive compounds capable of promoting antioxidant activity. They are important in feed, both for an adequate conservation and to avoid deterioration due to oxidative processes, as well as in species that consume it to mitigate the oxidative stress caused by exploitation conditions. In this context, the diet including $30 \%$ of avocado by-product showed the greatest antioxidant properties among the diets that included AP, so it can represent a greater advantage against oxidation by reactive species. Likewise, its formulation showed the greatest percentage of avocado paste, which would allow a significant decrease in using fish oil. On the other hand, a better use of avocado byproduct would represent a decrease in contamination when it is discarded in open-air garbage dumps. Therefore, avocado paste should be considered an interesting and novel by-product to be included as an alternative nutrient source in aquaculture diets, such as lipids and bioactive compounds with antioxidant properties.

\section{ACKNOWLEDGMENTS}

This article is a result of the thesis to obtain the Master of Science degree by the student Gabriela Poleth Hernández Ortega, developed in the Bioassays and Special Analysis Laboratory at the Unidad de Tecnología de Alimentos of the Universidad Autónoma de Nayarit, México. The authors acknowledge María Elena Luna Castañeda for her support in analytical determinations and Diana Fischer for translation and editorial services in English.

\section{REFERENCES}

Ahmed, M., Abdullah, N., Yusof, H.N., Shuib, A.S. and Razak, S.A. 2015. Improvement of growth and antioxidant status in Nile tilapia, Oreochromis niloticus, fed diets supplemented with mushroom stalk waste hot water extract. Aquaculture Research. 1-12.

A.O.A.C. 2012. Official methods of analysis, Association of official analytical chemist 19th edition, Washington D.C. USA.

Avilés-Ríos, E.D., Espinosa-García, J.A., Rentería-Flores, J.A., Mejía-Guadarrama, C.A., Mariscal-Landín, G. and CuarónIbargüengoytia, J. A. 2009. Disponibilidad de ingredientes no tradicionales con potencial de ser usados en la alimentación de cerdas gestantes en el Bajío mexicano. Veterinaria México. 40(4): 357-370.

Bureau, D.P. and Cho, C.Y. 1994. Ingredient quality: an essential factor in the formulation of cost-effective aquaculture diets. In: Expanding agriculture co-product uses in aquaculture feeds. Workshop Proceedings. 234-258.

Carbonera, F., Montanher, P.F., Palombini, S.V., Maruyama, S.A., Claus, T., Santos, H.M.C., Sargi, S.C., Matsushita, M. and Visentainer. J.V. 2014. Antioxidant capacity in tilapia fillets enriched with extract of acerola fruit residue. Journal of the Brazilian Chemical Society. 25(7): 1237-1245.

Daiuto, E., Tremocoldi, M., de Alencar, S., Lopes-Vieites, R. and Herbest, P. 2014. Composição química e atividade antioxidante da polpa e resíduos de abacate 'Hass'. Revista Brasileira de Fruticultura. 36(2): 417-424.

De Silva, S.S. and Hasan, M.R. 2007. Feeds and fertilizers: the key to long-term sustainability of Asian aquaculture. FAO. 497: 19-47.

Devi, A.M., Gondi, M., Sakthivelu, G., Giridhar, P., Rajasekaran, T. and Ravishankar, G. 2009. Functional attributes of soybean seeds and products, with reference to isoflavone content and antioxidant activity. Food Chemistry. 114: 771-776.

Escobar-Briones, L., Olvera-Novoa, M.A. and Puerto-Castillo, C. 2006. Avances sobre la ecología microbiana del tracto digestivo de la tilapia y sus potenciales implicaciones. Avances en nutrición acuícola VIII. VIII Simposium Internacional de Nutrición Acuícola. ISBN: 970-694-333.

FAO. 2005. Segmentación de los productos y perspectivas de mercado en los mercados del aguacate de la Comunidad Europea y los Estados Unidos. 2-3.

Galleguillos, M. and Romero, J.J. 1994. A quality parameter for fish meal: The biotoxicological score. Aquaculture. 124: 359363.

González-Salas, R., Romero-Cruz, O., Valdivié-Navarro, M. and Ponce-Palafox, J.T. 2014. Los productos y subproductos vegetales, animales y agroindustriales: Una alternativa para la alimentación de la tilapia. Revista Biociencias. 2(4): 240251.

Gorinstein, S., Poovarodom, S., Leontowicz, H., Leontowicz, M., Namiesnik, J., Vearasilp, S., Haruenkit, R., Ruamsuke, 
P., Katrich, E. and Tashma, Z. 2011. Antioxidant properties and bioactive constituents of some rare exotic Thai fruits and comparison with conventional fruits in vitro and in vivo studies. Food Research International. 44: 2222-2232.

Hernández-López, S. 2016. Valor nutritivo de pasta de aguacate y su efecto en la estabilidad oxidativa y calidad sensorial de carne de cerdo. Tesis para obtener el grado de doctor en ciencias biológico agropecuarias en el área de ciencias zootécnicas y veterinarias, Universidad Autónoma de Nayarit. Tepic, Nayarit.

Hinneburg, I., Dorman, D. and Hiltunen, R. 2006. Antioxidant activities of extracts from selected culinary herbs and spices. Journal of Food Chemistry. 97(1): 122-129.

Kim, S.S., Bueno-Galaz, G., Pham, M.A., Jang, J.W., Oh, D.H., Yeo, I.K. and Lee, K.J. 2009. Effects of dietary supplementation of a Meju, fermented soybean meal, and Aspergillus oryzae for juvenile parrot fish (Oplegnathus fasciatus). The AsianAustralasian Association of Animal Production Societies. 22(6): 849-856.

Kim, S.S., Rahimnejad, S., Kim, K.W., Lee, B.J. and Lee, K.J. 2013. Effects of dietary supplementation of spirulina and quercetin on growth, innate immune responses, disease resistance against Edwardsiella tarda, and dietary antioxidant capacity in the juvenile olive flounder Paralichthys olivaceus. Fisheries and Aquatic Sciencies. 16(1): 7-14.

Kuskoski, E., Asuero, A., Troncoso, A., Garcia-Parilla, M. and Fett, R. 2004. Actividad antioxidante de pigmentos antocianicos. Revista Ciência e Tecnologia de Alimentos. 24(4): 691-693.

Laguerre, M., Lecomte, J. and Villeneuve, P. 2007. Evaluation of the ability of antioxidants to counteract lipid oxidation: Existing methods, new trends and challenges. Progress in Lipid Research. 46(5):244-282.

Lim, S.J. and Lee, K.J. 2011. A microbial fermentation of soybean and cottonseed meal increases antioxidant activity and gossypol detoxification in diets for Nile Tilapia, Oreochromis niloticus. Journal of the World Aquaculture Society. 42: 494503.

Lundebye, K., Hove, H., Mage, A., Bohne, V. and Hamre, K. 2010. Levels of synthetic antioxidants (ethoxyquin, butylated hydroxytoluene and butylated hydroxyanisole) in fish feed and commercially farmed fish. Food Additives and Contaminants. 27: 1652-1657.

Lv, J., Yu, L., Lu, Y., Niu, Y., Liu, L., Costa, J. and Yu, L.L. 2012. Phytochemical compositions, and antioxidant properties, and antiproliferative activities of wheat flour. Food Chemistry. 135: 325-331.

Maisuthisakul, P. and Gordon, M.H. 2009. Antioxidant and tyrosinase inhibitory activity of mango seed kernel by product. Food Chemistry. 117: 332-341.

Meyer, D., Castillo, C. and Triminio, S. 2006. Manual de prácticas de acuacultura. 3a Ed. Escuela Agrícola Panamericana, Honduras. 111.

Montoya, C., Vega, F., Nolasco, H., Espinosa, L., Carrillo, O. and Olvera, F. 2014. Effects of dietary antioxidant of tomato extract and lycopene on Carassius auratus and Xiphophorus maculatus. Revista de Medicina Veterinaria Zootecnica Córdoba. 19(2): 4059-4071.

Morales, F. and Jiménez-Pérez, S. 2001. Free radical scavenging capacity of Maillard reaction products as related to colour and fluorescence. Journal of Food Chemistry. 72: 119-125.

Moreno, E., Ortiz, B. and Restrepo, L. 2014. Contenido total de fenoles y actividad antioxidante de pulpa de seis frutas tropicales. Revista Colombiana de Química. 43(3): 41-48.
Obasa, S.O., Alatise, S.P., Omoniyi, I.T., Alegbeleye, W.O. and George F.A. 2013. Evaluation of fermented mango (Mangifera indica) seed meal in the practical diet of Nile tilapia, (Oreochromis niloticus) fingerlings. Croatian Journal of Fisheries. 71: 116-123.

Oniszczuk, T., Oniszczuk, A., Gondek, E., Guz, L., Puk, K., Kocira, A., Kusz, A., Kamila Kasprzak, K. and Wójtowicz, A. 2019. Active polyphenolic compounds, nutrient contents and antioxidant capacity of extruded fish feed containing purple coneflower (Echinacea purpurea (L.) Moench.). Saudi Journal of Biological Sciences. 26: 24-30.

Opitz, S.E.W., Smrke, S., Goodman, B.A. and Yeretzian, C. 2014. Methodology for the measurement of antioxidant capacity of coffee. Processing and Impact on Antioxidants in Beverages. 253-264.

Pellegrini, N., Serafini, M., Colombi, B., Del Rio, D., Salvatore, S., Bianchi, M. and Brighenti, F. 2003. Total antioxidant capacity of plant foods, beverages and oils consumed in Italy assessed by three different in vitro assays. The Journal of Nutrition. 133(9): 2812-2819.

Re, R., Pellegrini, N., Proteggente, A., Pannala, A., Yang, M. and Rice-Evans, C. 1999. Antioxidant activity applying an improved ABTS radical cation decolorization assay. Journal Free Radical Biology and Medicine. 26: 9-10.

Rodríguez-Carpena, J.G., Morcuende, D., Andrade, M.J., Kylli, P. and Estévez, M. 2011. Avocado (Persea americana Mill.) phenolics, in vitro antioxidant and antimicrobial activities, and inhibition of lipid and protein oxidation in porcine patties. Journal of Agricultural and Food Chemistry. 59: 5625-5635.

SAGARPA. 2009. Modelo tecnológico de cultivo de tilapia (Oreochromis sp.) en jaulas. [línea]. Disponible en https:// docplayer.es/2859909-Introduccion-al-cultivo-de-la-tilapia. html. Consultado el 02 de abril del 2017.

Saha, S., Roy, R., Sen, S. and Ray, A. 2006. Characterization of cellulase-producing bacteria from the digestive tract of tilapia, Oreochromis mossambica (Peters) and grass carp, Ctenopharyngodon idella (Valenciennes). Aquaculture Research. 37: 380-388.

SIAP. 2018. Servicio de información agroalimentaria y pesquera (SIAP). Atlas agroalimentario 2018. Primera edición. México D.F. 222.

Stintzing, F., Herbach, K., Mosshammer, M., Carle, R., Yi, W., Sellappan, S., Akoh, C., Bunch, R. and Felker, P. 2005. Color, betalain pattern, and antioxidant properties of cactus pear (Opuntia spp.) clones. Journal of Agricultural and Food Chemistry. 53: 442-451.

Tacon, A. 1989. Nutrición y alimentación de peces y camarones cultivados. Manual de capacitación. Programa Cooperativo Gubernamental. FAO. Documento de campo No. 4. Programa AQUILA I. Brasilia-Brasil.

Thorat, I.D., Jagtap, D.D., Mohapatra, D., Joshi, D.S., Sutar, R.F. and Kapdi, S.S. 2013. Antioxidants, their properties, uses in food products and their legal implications. International Journal of Food Studies. 2: 81-104.

Wang, W., Bostic, T. R., and Gu, L. 2010. Antioxidant capacities, procyanidins and pigments in avocados of different strains and cultivars. Food Chemistry. 122 (4): 1193-1198.

Wang, M., Zheng, Y., Khuong, T. and Lovatt, C. 2012. Effect of harvest date on the nutritional quality and antioxidant capacity in "Hass" avocado during storage. Food Chemistry. 135: 694-698. 